\title{
Denis Murphy, the University of Queensland and Labour History, 1966-83: A Reassessment
}

\section{Bradley Bowden*}

This paper explores the flowering of labour history at the University of Queensland between 1966 and 1983; a blossoming that not only laid foundations for the discipline in Queensland but which also provided an interpretation at odds with the then dominant "Old Left" historiography. It is argued that, in addition to Denis Murphy's efforts, there were four complex and unstable factors behind this flowering: initial support from Queensland Labor, senior mentors (notably Roger Joyce and Colin Hughes), a favourably inclined University of Queensland Press manager and a reservoir of labour history theses. While these factors underpinned publications between 1966 and 1983, by the latter date their impetus was largely exhausted. Subsequent advances occurred in less propitious circumstances.

The 1960s and 1970s were seminal years for the discipline of labour history. Although the writing of Australian labour history was hardly new, having been practiced both by labour activists (John Norton, John Black, W. G. Spence) and the university trained (most notably V. G. Childe and Brian Fitzpatrick), it was only at this time that the discipline took on a coherent and sustained existence. Much of the discipline's expansion took place at the Australian National University (ANU) and its Research School of Social Sciences. From the ANU's august halls emanated not only this journal's first issue in 1962, but also the scholarship of Eric Fry, Robin Gollan, P. G. Macarthy, Jim Hagan, John Merritt and others. In broad terms, their work was associated with what came to be called the "Old Left." Work relationships, class formation and patterns of unionisation were seen as the key drivers of history. In assessing the Labor Party they tended to share the viewpoint previously enunciated by Childe and Fitzpatrick: that Labor's formation was historically positive but its potential had been undermined by opportunist politicians and middle-class moderates. ${ }^{1}$

There was, however, more than one source to the disciplinary spring of labour history with the University of Queensland (UQ) History Department also emerging as a major source of research. From 1966, when June Stoodley published an article on Queensland gold-mining unionism in Labour History, ${ }^{2}$ until 1983, when Denis Murphy's last edited book, The Big Strikes, was released, UQ scholars provided not only a foundation for subsequent Queensland research but also an interpretation that highlighted Labor's multi-class appeal. During these years, 13 articles were published in Labour History by academics employed within the Department. ${ }^{3}$ Murphy - employed by the Department from 1966 until his election to Parliament in 1983 -

1. See John Merritt, "R. A. Gollan, E. C. Fry and the Canberra Years of the Australian Society for the Study of Labour History," Labour History, no. 94 (May 2008): 17-23; John Merritt, "Labour History," in New History: Studying Australian History Today, ed. G. Osbourne and W. F. Mandle (Sydney: Allen \& Unwin, 1982), 113-41; Frank Bongiorno, "Australian Labour History: Contexts, Trends and Influences," Labour History, no. 100 (May 2011): 1-18.

2. June Stoodley, "The Development of Gold-Mining Unionism in Queensland in the Late Nineteenth Century," Labour History, no. 14 (May 1966): 14-27.

3. The composition of the 13 articles is outlined below. 
published five edited books, either alone or in collaboration, and two sole-authored biographies. ${ }^{4}$ This opus of work caused Murphy to be regarded, Frank Bongiorno records, as "one of the giants of labour history in this country."

Unsurprisingly, given his place in labour history's pantheon, Murphy's contribution has previously been discussed at length. After Murphy's death, Brian Costar, who studied for his PhD when Murphy was on staff, recorded that Murphy wrote history "to equip the modern Labor party for the task of making Australia a just society." ${ }^{6}$ In 1985, Verity Burgmann made a more critical judgement, identifying Murphy (along with Bede Nairn and D. W. Rawson) as one of the "conservative labour historians" who understated socialism's role in Labor's formation. ${ }^{7}$ During 2006, the Journal of the Royal Historical Society of Queensland (JRHSQ) dedicated a special edition to Murphy's work with articles from Bongiorno, Kay Saunders, Ray Evans and Joanne Scott. Of these contributors, both Saunders and Evans were long-term colleagues of Murphy at UQ. Bongiorno's account drew on Murphy's personal papers. ${ }^{8}$ Even the History Department's machinations under Gordon Greenwood (Head, 1949-78) are well-recorded with reflections from both Greenwood's sympathisers (Hudson, Moses, Shaw and Siracusa) $)^{9}$ and critics (Radi, Saunders and Scott). ${ }^{10}$

Despite the research encompassing both Murphy's career and the UQ History Department, there is nevertheless room for reassessment. Rather than it being simply a case as Evans has suggested, that "to all intents and purposes, Denis Murphy was Queensland Labour History,"11 this study - drawing upon the Departmental records and personal papers located within UQ's Gordon Greenwood Collection, Murphy's personal papers and the University of Queensland Press (UQP) archives ${ }^{12}$ - argues that labour history's achievements and failings were shaped, in addition to Murphy's personal efforts, by a confluence of four complex and unstable factors. The first was Murphy's relationship with the Labor Party. This most benefited the writing of labour history when Tom Burns served as State Secretary (1965-72). Burns not only

4. D. J. Murphy, R. B. Hughes and Colin Hughes, eds, Prelude to Power: The Rise of the Labour Party in Queensland, 1885-1915 (Milton: Jacaranda Press, 1970); D. J. Murphy, ed., Labor in Politics: State Labor Parties in Australia, 1880-1920 (St Lucia: University of Queensland Press (UQP), 1975); D. J. Murphy, T. J. Ryan: A Political Biography (St Lucia: UQP, 1975); D. J. Murphy, R. B. Hughes and Colin Hughes, eds, Queensland Political Portraits 1859-1952 (St Lucia: UQP, 1978); D. J. Murphy, R. B. Hughes and Colin Hughes, eds, Labor in Power: The Labor Party and Governments in Queensland 1915-1957 (St Lucia: UQP, 1980); D. J. Murphy, Bill Hayden: A Political Biography (Sydney: Angus \& Robertson, 1980); D. J. Murphy, ed., The Big Strikes: Queensland 1889-1965 (St Lucia: UQP, 1983).

5. Frank Bongiorno, "The Importance of Being Practical: DJ Murphy and Australian Labour History," Journal of the Royal Historical Society of Queensland (hereafter JRHSQ) 19 (December 2006): 49.

6. Brian Costar, "Denis Murphy: Labor Activist, Labour Historian," Australian Journal of Politics $\mathcal{E}$ History 34 (April 1988): 93.

7. Verity Burgmann, "In Our Time": Socialism and the Rise of Labor, 1885-1905 (Sydney: Allen \& Unwin, 1985), 15.

8. Bongiorno, "The Importance of Being Practical," 31-53; Kay Saunders, "Denis Murphy at the University of Queensland," JRHSQ 19 (December 2006): 14-30; Raymond Evans, "Reconsidering Murphy and Ryan," JRHSQ 19 (December 2006): 54-64; Joanne Scott, "Where are the Women? Denis Murphy and Labour History," JRHSQ 19 (December 2006): 138-49.

9. W. Hudson, "Gordon Greenwood: A Student's Recollection," Australian Journal of Politics E History 29, (August 1983): 202-205; John Moses, George Shaw and Joseph Siracusa, "Editorial," Australian Journal of Politics \& History 29 (August 1983): 195-96.

10. Heather Radi, "Thanks Mum," in Against the Odds: Fifteen Professional Women Reflect on Their Lives and Careers, eds, Madge Dawson and Heather Radi (Sydney: Hale \& Iremonger, 1984), 169-85; Saunders, "Denis Murphy," 14-30; Scott, "Where are the Women," 138-49.

11. Evans, "Reconsidering Murphy and Ryan," 56.

12. All cited records are held at the Fryer Library, University of Queensland (UQ) under the following catalogue numbers: Greenwood Collection, UQFL515; Murphy Papers, UQFL129; UQP Archives, UQFL198. Hereafter references will be by catalogue number. 
gave researchers access to records, he also provided the impetus for Murphy's first edited book, Prelude to Power. ${ }^{13}$ A second factor in the vitality of labour history at UQ - the relationship between Murphy and his two academic mentors, Roger Joyce (his PhD supervisor) and Colin Hughes, and also that between the Department's Australian specialists and Greenwood - was also complex. Prior to 1980, Joyce and Hughes served as co-editors for all but two of Murphy's books (Labor in Politics and T. J. Ryan being the exceptions). Increasingly, however, the duo, who did not share Murphy's Labor politics, sought to restrain their protégée. Strains came to a head in the writing of Queensland Political Portraits, when Joyce and Hughes scuttled Murphy's efforts to extend discussion into the realm of contemporary Queensland politics. Similarly, while the relationship between Greenwood and UQ's Australian history specialists steadily deteriorated, the latter nevertheless benefited from Greenwood's capacity to acquire resources and exert influence, a fact demonstrated when Greenwood persuaded L. F. Crisp, one of Murphy's PhD examiners, to reverse his recommendation that Murphy's $\mathrm{PhD}$ thesis be rejected. ${ }^{14} \mathrm{~A}$ third factor in labour history's success was the support of Frank Thompson, long-term manager of the UQP. With the exception of Murphy's first book, Prelude to Power, and his biography of Hayden, all of Murphy's books were released by UQP. Published in the face of growing losses, Thompson's actions eventually alarmed university administrators. When in 1979 the University curtailed Thompson's independence, the death-knell was sounded on a golden era of labour history book publishing. ${ }^{15}$ The late 1970s also witnessed the exhaustion of a fourth element that underpinned publications: a reservoir of labour history theses (including political biographies and studies on Queensland's social structure). In 1970, when Prelude to Power brought much of this work to public attention, 35 such theses existed. Thereafter, however, their number diminished. Those who did undertake labour history theses were increasingly attracted to "New Left" topics such as race and gender. In these areas, Murphy's junior colleagues, Saunders and Evans, were better equipped as supervisors and mentors. In consequence, of the factors that had underpinned the success of Murphy and the school of labour history that he represented, only Murphy's relationship with the Labor Party was in a positive state by 1983.

\section{Foundations: Labour History in the UQ History Department to 1970}

The outpouring of labour history publications from UQ's History Department during the 1970s appeared to spring from almost nowhere. In truth, it had deep roots, drawing upon more than two decades of unpublished activity; activity first heralded in 1947 when Sam Rayner - who later served as UQ's Academic Registrar during the turbulent 1960s - submitted his Master's thesis: "The Evolution of the Queensland Labour Party to 1907." The reasons behind the suite of labour history theses that followed in Rayner's wake are unclear. Few acknowledged either their supervisors or the reasons for their studies - deficiencies that are now, given the passage of time, impossible to rectify. What is nevertheless evident is that the

13. Denis Murphy to Tom Burns, 22 February 1968, Box 41, UQFL129; Denis Murphy to Brian Dickey, 25 March 1970, Folder 3, Box 40, UQFL129.

14. L. F. Crisp, Examiner's Report on PhD Thesis of D. J. Murphy, 10 April 1972, Box 41, UQFL129; L.

F. Crisp to D. J. Munro, 23 May 1972, Box 41, UQFL129.

15. L. R. Page to Frank Thompson, 5 December 1978, Box 57, Folder 2, UQFL198. 
appointment of Gordon Greenwood as McCaughey Chair of History and Head in 1949 did not initiate the stream of labour history theses, even though Greenwood stated in his letter of application that it was "natural for an Australian historian early in his career to work in either the Pacific or Australian fields since material is more readily available."16 Many of the most significant labour history theses to emerge from the Department - Rayner's Master's thesis (1947), Robert McCaig's Honours thesis, "Labour Organisation and Objectives in Queensland, 1890-1920" (1950), M. G. Birrell's Honours thesis, "T. J. Ryan and the Queensland Labour Party" (1951), June Stoodley's Honours thesis, "Social Aspects of Early Goldmining in Queensland" (1951), Don Dignam's Honours thesis, "Sir Thomas Mcllwraith" (1951), and P. Bray's Honours thesis, "E. G. Theodore and the Queensland Labor Movement" (1951) were completed either prior to Greenwood's arrival or too soon afterwards for him to have had a guiding influence.

Rather than being inspired by internal factors, these early theses appear to have been motivated by a sense of intellectual opportunity and / or a desire to engage with traditions of non-academic labour history. The former is most evident in Rayner's thesis, one of the few to elucidate reasons for his research. The "early history of Labour in Queensland" was, Rayner observed, "virgin territory, which could be explored only through a thorough survey of contemporary newspapers, the Parliamentary debates, and official reports." ${ }^{17}$ Empirically rich, Rayner's thesis included mini-biographies of Queensland labour's pioneers. Thirty are listed in Appendix $\mathrm{H}$ alone; summaries that later found their way, almost verbatim, into an appendix of Murphy's Labor in Politics. ${ }^{18}$ Birrell's thesis on T. J. Ryan also explored virgin pastures. Echoing themes later taken up by Murphy in his PhD, Birrell argued that a study of Ryan's career revealed how "a powerful personality" could "significantly effect" political organisations. ${ }^{19}$ In contrast, McCaig's thesis (1950) was a conscious defence of the pioneering role of early socialist activists, most notably William Lane, McCaig beginning his thesis by acknowledging the support received from Lane's brother, Ernie, and two other pioneers, J. S. Collings and J. A. Moir. ${ }^{20}$

There soon emerged a more prosaic reason for completing a labour history thesis: jobs. As Greenwood observed in the early 1960s, "Junior Lectureships and Senior Research positions ... are usually awarded to recent Honours graduates." ${ }^{21}$ Of those who completed theses in the Department prior to 1970 at least six obtained permanent positions: Dignam, Murphy, Evans, Paul Crook, John Moses and Ross Johnson. Three others - Tom Truman, Charles Grimshaw and June Stoodley - completed degrees while on staff. Heather Radi studied while working as Greenwood's research assistant. Rayner, as noted earlier, became University Registrar. Others - Grant Hannan, Geoff Marginson, J. B. Dalton, W. J. Hudson and Jane Phillips - found work in other universities. ${ }^{22}$

16. Gordon Greenwood, Application: McCaughey Chair of History, c. December 1948, Folder 8, Box 7, UQFL516.

17. S. A. Rayner, "The Evolution of the Queensland Labour Party to 1907" (MA thesis, University of Queensland, 1947), ii-iii.

18. Ibid., Appendix H; D. J. Murphy, "Queensland," in Murphy, Labor in Politics, 216-23.

19. M. G. Birrell, "T. J. Ryan and the Queensland Labour Party" (BA Hons thesis, UQ, 1951), i.

20. Robert McCaig, "Labour Organisation and Objectives in Queensland, 1890-1920," (BA Hons thesis, UQ, 1950), ii.

21. Gordon Greenwood, Honours in History, c. 1964, 2, Folder 10, Box 7, UQFL516.

22. Grimshaw and Hudson completed theses on diplomatic history. 


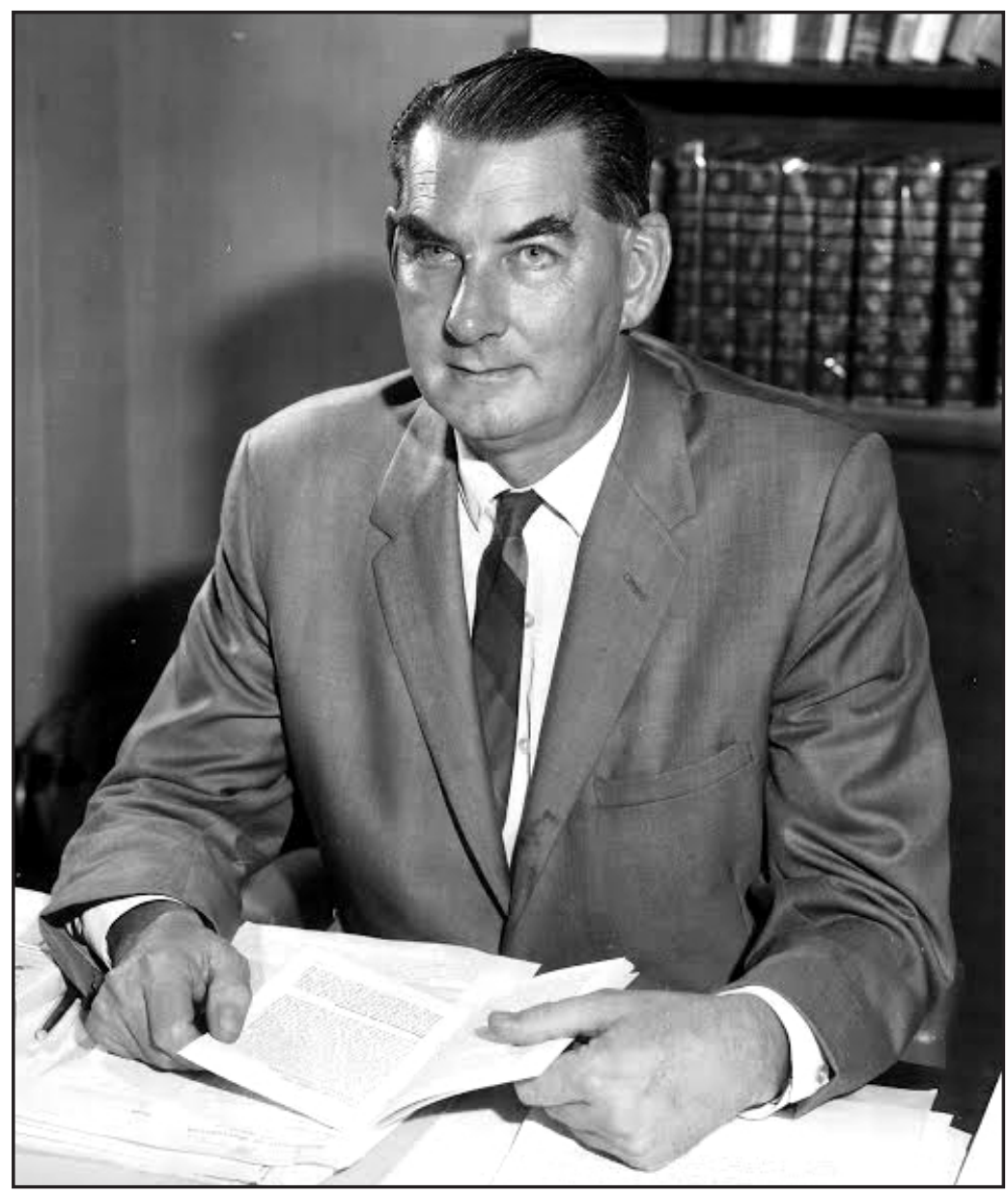

Gordon Greenwood, c 1960

McCaughey Professor of History and Head of Department, 1949-78. Hard-drinking and hard smoking, Greenwood initially looked favourably on the writing of labour history. Over time, however, his relations with his Department's Australian history specialists became increasingly problematic.

Courtesy: University of Queensland Archives

In many ways, of course, the transition from Honours Degree to academic position at UQ simply reflected a general trend as universities expanded exponentially. The UQ Department also resembled other universities in having an autocratic Head. A heavy smoker and even heavier drinker, Greenwood inculcated what has been called a "combative masculine culture." ${ }^{23}$ In terms of research, his passion was for diplomatic history. As time went by Greenwood's behaviour grated on many. By 1970, staff were in revolt, a Departmental "Assembly" empowering an Executive to vet appointments and other decisions. If Greenwood was an autocrat he was also, as one critic acknowledged, "uniquely capable." ${ }^{24}$ Between 1949 and 1975 the History

23. Saunders, "Denis Murphy," 20; Radi, “Thanks Mum," 169-75.

24. Don Dignan, Chairman's Report, UQ History Department Staff Committee, September 1978, Box 32, UQFL129. 
Department's numbers grew - despite the loss of its Politics wing in 1965 - from four (A. A. Morrison, R. G. Neale, Charles Grimshaw and June Stoodley) to 35. A longterm member of the University's Senate, Greenwood's power extended throughout the University. When the University initiated cost-reductions, Greenwood waged effective rear-guard actions, Murphy (a Greenwood critic) conceding in 1977 that "Professor Greenwood had looked after staff numbers." ${ }^{25}$ Greenwood was also close to Frank Thompson, serving on UQP's governing Publication Committee - a body that decided, on Thompson's advice, which books to publish. For his part, Thompson funded the loss-making Journal of Politics \& History; a venture Greenwood founded in 1955, subsequently serving as Editor until his retirement in $1982 .{ }^{26}$ In return, Greenwood often subsidised losses incurred in publishing the books of Departmental members.

Although "temperamentally conservative," ${ }^{27}$ Greenwood countenanced not only labour history research but also radical interpretations. Greenwood's benevolence was indicated when in 1956 the University of New England's asked him to provide a confidential assessment on Robin Gollan, who had applied for a job at that University. Greenwood's report strongly supported appointment, observing that while Gollan was guided by a "near-Marxist interpretation" he was nevertheless "one of the ablest" of Australia's emerging historians.$^{28}$ Greenwood's opinion was also highlighted when he invited Gollan to submit a chapter for inclusion in what was to be Greenwood's most significant career publication, Australia: A Social and Political History; a work Saunders has described as "a landmark publication." ${ }^{29}$ In his own chapters, Greenwood emphasised the labour movement's centrality in the Australia experience, noting that Labor's formation "changed the whole character of political activity." ${ }^{30}$ Echoing themes found in Rayner's thesis, Greenwood also argued that the Labor Party was one divided between socialist "idealists" and moderate "practical men." Only when the latter prevailed was Labor successful. ${ }^{31}$

In the decade and a half after the publication of Australia, the UQ History Department witnessed the completion of 25 theses with a labour history theme. As Table 1 indicates, theses fell into three broad areas. First, reflecting Roger Joyce's presence on staff, who served in the Department from 1953 until 1975, there were political biographies; a research stream that included studies of William Kidston, James Scullin and Andrew Fisher. Second, there were theses that looked at colonial social relationships, a topic that reflected A. A. Morrison's expertise. The most popular research area, however, involved studies of the Queensland labour movement's industrial and political wings (and its foes), an area that produced ten

25. Minutes of Meeting between Gordon Greenwood and History Department Staff Delegation, 8 June 1977, Folder 5, Box 8, UQFL516.

26. UQP Publication Committee, Memorandum to Deputy Vice-Chancellor, c. December 1968, Folder 2, Box 573, UQFL198.

27. D. P. Crook, "Obituary: Gordon Greenwood," Australian Academy of Social Sciences: Annual Report, 1986-87 (Canberra: Australian Academy of Social Sciences, 1987), 49.

28. Gordon Greenwood to Dr Madgwick (Vice-Chancellor, University of New England): Report on Robin Gollan, 14 September 1956, Folder 14, Box 7, UQFL516.

29. R. A. Gollan, "Nationalism, the Labour Movement and the Commonwealth," in Australia: A Social and Political History, ed. Gordon Greenwood (Sydney: Angus \& Robertson, 1955), 145-95; Saunders, "Denis Murphy," 20.

30. Gordon Greenwood, "National Development and Social Experimentation," in Greenwood, Australia, 200.

31. Greenwood, "National Development," 196-257; Gordon Greenwood, "Development in the Twenties," in Greenwood, Australia, 289. 
theses between 1955 and 1970. One reason for the productivity in this latter area was the comparative ease of gaining access to Queensland Labor's records. As Murphy noted in 1970, "the party has been very helpful over the years with using their records for students' theses." ${ }^{32}$ The Queensland Trades and Labour Council (TLC) under its Communist Secretary, Alex Macdonald, also appears to have been accommodating. ${ }^{33}$

Table 1. Labour Themed Theses at UQ History Department, 1947-83

\begin{tabular}{|c|c|c|c|}
\hline Year & Author & Thesis Title & Degree \\
\hline 1947 & Samuel Rayner & $\begin{array}{l}\text { The Evolution of the Queensland Labour Party to } \\
\qquad 1907\end{array}$ & MA \\
\hline 1950 & Robert McCaig & $\begin{array}{l}\text { Labour Organisation and Objectives in Queensland, } \\
\qquad 1890-1920\end{array}$ & BA (Honours) \\
\hline 1951 & M. G. Birrell & T. J. Ryan and the Queensland Labour Party & BA (Honours) \\
\hline 1951 & June Stoodley & Social Aspects of Early Goldmining in Queensland & BA (Honours) \\
\hline 1951 & Don Dignam & Sir Thomas Mcllwraith & BA (Honours) \\
\hline 1951 & P. Bray & E. G. Theodore and the Queensland Labor Movement & BA (Honours) \\
\hline 1951 & Louis Green & Queensland Attitudes to Federation & BA (Honours) \\
\hline 1953 & John Vockler & Sir Samuel Griffith & BA (Honours) \\
\hline 1953 & Tom Truman & $\begin{array}{c}\text { Pressure Groups, Parties and Politics of the Australian } \\
\text { Labour Movement }\end{array}$ & MA \\
\hline 1953 & John Mathews & $\begin{array}{l}\text { The Influence of William Lane on the Queensland } \\
\text { Labour Party }\end{array}$ & BA (Honours) \\
\hline 1954 & H. Kenway & The Pastoral Strikes of 1891 and 1894 & BA (Honours) \\
\hline 1956 & Bruce Knox & Sir Arthur Morgan & BA (Honours) \\
\hline 1956 & R. E. Cameron & Pastoralist Organisations in Queensland, 1884-1900 & BA (Honours) \\
\hline 1958 & Paul Crook & Aspects of Brisbane Society in the 1880 s & BA (Honours) \\
\hline 1958 & Harrison Bryan & The Political Career of John Macrossan & MA \\
\hline 1959 & John Moses & Australian Attitudes to New Settlers in Queensland & BA (Honours) \\
\hline 1960 & J. M. Bertie & Non-Labour Politics in North Queensland 1907-29 & BA (Honours) \\
\hline 1960 & M. Stubbs Brown & Secondary Industries of Queensland 1875-1900 & BA (Honours) \\
\hline 1961 & J. B. Dalton & The Queensland Labour Movement 1889-1915 & BA (Honours) \\
\hline 1961 & Derek Volker & $\begin{array}{l}\text { The Australian Labour Party in Queensland, } \\
\qquad 1927-1935\end{array}$ & BA (Honours) \\
\hline 1962 & K. J. Wanka & William Kidston: a Political Biography & BA (Honours) \\
\hline 1963 & Rosemary Lawson & Immigration into Queensland 1870-90 & BA (Honours) \\
\hline 1964 & June Stoodley & $\begin{array}{l}\text { The Queensland Gold-Miner in the late Nineteenth } \\
\text { Century }\end{array}$ & MA \\
\hline 1964 & S. K. Proctor & $\begin{array}{l}\text { The Brisbane Branch of the Plumbers and Gasfitters } \\
\text { Employees Union, 1904-19 }\end{array}$ & BA (Honours) \\
\hline 1965 & D. J. Murphy & $\begin{array}{l}\text { The Establishment of State Enterprises in } \\
\text { Queensland, 1915-18 }\end{array}$ & MA Qualifying \\
\hline 1965 & W. R. Johnston & $\begin{array}{l}\text { The Relationship between Law, the State and the } \\
\text { Community in Colonial Queensland }\end{array}$ & MA \\
\hline 1965 & Raymond Evans & $\begin{array}{l}\text { European - Aboriginal Relations in Queensland, } \\
\qquad 1880-1910\end{array}$ & BA (Honours) \\
\hline
\end{tabular}

32. Denis Murphy to Brian Dickey, 25 March 1970, Folder 3, Box 40, UQFL129.

33. See Alex Macdonald to D. J. Murphy, 23 October 1967, Box 41, UQFL129. 


\begin{tabular}{|c|c|c|c|}
\hline 1966 & Grant Hannan & The New Australia Movement & MA \\
\hline 1967 & John Colegrove & J. H. Scullin: Prime Minister in Adversity & BA (Honours) \\
\hline 1967 & $\begin{array}{l}\text { Geoffrey Mar- } \\
\text { ginson }\end{array}$ & Andrew Fisher: the Colonial Experience 1885-1901 & BA (Honours) \\
\hline 1969 & Jane Phillips & The Townsville Meatworkers Strike & BA (Honours) \\
\hline 1969 & R. J. Sullivan & Early Labour in Queensland & MA Qualifying \\
\hline 1969 & Raymond Evans & Charitable Institutions of Queensland to 1919 & MA \\
\hline 1970 & Kathryn Cronin & $\begin{array}{l}\text { The Chinese Question in Queensland during the } \\
\text { Nineteenth Century }\end{array}$ & $\mathrm{PhD}$ \\
\hline 1970 & Ronald Lawson & Brisbane Society in the $1890 \mathrm{~s}$ & $\mathrm{PhD}$ \\
\hline 1971 & Glen Lewis & The Ports of Queensland 1859-1939 & PhD \\
\hline 1972 & D. J. Murphy & T. J. Ryan: A Political Biography & $\mathrm{PhD}$ \\
\hline 1972 & Glenda Strachan & The Brisbane General Strike of 1972 & BA (Honours) \\
\hline 1972 & Neil Stewart & Queensland Pastoral Strikes, 1891 & BA (Honours) \\
\hline 1972 & Jim Prentice & The New Left & MA Qualifying \\
\hline 1973 & Carmel Shute & Australian Woman and the Great War & BA (Honours) \\
\hline 1973 & David Gibson & Hon. Francis Ford: His Life and Times & BA (Honours) \\
\hline 1974 & Anna Cribb & The Maritime Strike of 1890 & BA (Honours) \\
\hline 1974 & G. E. Fisher & The Watson Labor Government & BA (Honours) \\
\hline 1974 & Gerard Dalton & The Queensland Labour Movement 1919-29 & BA (Honours) \\
\hline 1974 & Kay Saunders & $\begin{array}{c}\text { Uncertain Bondage: Indentured Labour in Queensland } \\
\text { to } 1907\end{array}$ & PhD \\
\hline 1975 & Susan Barnett & The Queensland Native Police in the 1870 s & BA (Honours) \\
\hline 1975 & Ross Donlon & Cultural Change in Australia, 1939-45 & BA (Honours) \\
\hline 1975 & Rosemary Gill & Biography of T. J. Byrnes & BA (Honours) \\
\hline 1975 & Jan Walker & $\begin{array}{l}\text { Aboriginal-White Contact in the Maryborough District, } \\
\qquad 1860-1900\end{array}$ & BA (Honours) \\
\hline 1976 & Ann McGrath & $\begin{array}{l}\text { Exile to Bondage Asiatic Indenture into Colonial } \\
\text { Queensland }\end{array}$ & BA (Honours) \\
\hline 1980 & Raymond Evans & $\begin{array}{l}\text { Loyalty and Disloyalty: Social and Ideological Conflict } \\
\text { in Queensland during the Great War }\end{array}$ & $\mathrm{PhD}$ \\
\hline 1981 & Brian Costar & $\begin{array}{l}\text { Labor, Politics and Unemployment in Queensland } \\
\text { during the Great Depression }\end{array}$ & $\mathrm{PhD}$ \\
\hline
\end{tabular}

The ideological thrust of the theses completed between 1955 and 1970 was almost universally in tune with the views expounded by Greenwood and Rayner: that the labour movement was divided between "idealists" and "practical men" with Labor's victories associated with the latter's ascendancy. This argument was most fully developed in Dalton's thesis, "The Queensland Labour Movement, 1889-1915," an abbreviated version of which later appeared in the introduction to Prelude to Power. While sharing the view that Labor's successes depended on the victory of "moderates," it differed in arguing that Labor owed its local origins to Queensland's "liberal ethos" - not socialism. The party's roots, he also contended, were found not in the strikes of the 1890s, but in the reform movements of the 1880s. ${ }^{34}$ Such themes later became cornerstones of Murphy's work.

34. J. B. Dalton, “The Queensland Labour Movement 1889-1915” (BA Hons. Thesis, UQ, 1961), unpaged conclusion. 


\section{Achievements, 1970-78}

In the mid-1960s the body of labour history research found within the History Department's thesis collection was still unpublished; an outcome that partly reflected the absence of a suitably motivated research mentor. Instead, intellectual and organisational leadership in the field of Queensland labour history was provided by an amateur enthusiast, Joe Harris. Employed by the Building Workers Industrial Union, Harris also served as inaugural President of the Brisbane Labour History Society. When the first issue of this journal was published in 1962, Harris contributed an article called simply "Queensland Labour History." In this piece, Harris exploded the myth that William Lane had established the Brisbane TLC, correctly informing readers that the TLC's founder was William Galloway, the President of the Seamen's Federation's local branch. While in terms of published research this was a novel insight - running contrary to the view expounded by Timothy Coghlan, Lloyd Ross and Gollan - Galloway's role in the TLC's formation had been highlighted much earlier in Rayner's thesis, a work that Harris does not appear to have read. ${ }^{35}$ Harris's leadership role in Queensland labour history was confirmed in 1970 when he published The Bitter Fight: A Pictorial History of the Australian Labour Movement, a work that owed its existence to Frank Thompson. As Harris acknowledged in the book's foreword, he was introduced to Thompson by Grant Hannan, a recent UQ history graduate. Thompson then published the book under UQP's banner. ${ }^{36}$

Analysis of the issues of Labour History also highlights the initial inability of the UQ History Department to turn its research reservoir into publications. During the 1960s this journal published ten Queensland-themed articles. Only three were from the UQ Department, a total almost matched by Joe Harris's efforts (two). ${ }^{37}$ The Department's efforts were, moreover, equalled by ANU-based historians. ${ }^{38}$ Of the three articles from the UQ Department, two were from the long-serving June Stoodley, both drawing on her Honours and Master's theses..$^{39}$ The third came from Murphy, being based upon his recently completed Master's Qualifying thesis. ${ }^{40}$ Admittedly, the UQ Department's publication total was boosted by one from John Merritt, who worked at UQ in the early 1960s. However, not only was Merritt ANUtrained, the focus of his article, a Perth building strike, was unrelated to the state in which he was domiciled. ${ }^{41}$

35. Joe Harris, "Queensland Labour History," Bulletin for the Study of Labour History, no. 1 (January 1962): 16-24. Also Timothy Coghlan, Labour \& Industry in Australia, vol. 3 (Melbourne: Macmillan, 1969), 1519; Lloyd Ross, William Lane and the Australian Labour Movement (Sydney: Lloyd Ross, 1935), 43-44; Robin Gollan, Radical and Working Class Politics (Melbourne: Melbourne University Press, 1960), 124

36. Joe Harris, The Bitter Fight: A Pictorial History of the Australian Labor Movement (St Lucia: UQP, 1970), viii.

37. Harris, "Queensland Labour History," 16-24; Joe Harris, "The Struggle against Pacific Island Labour," Labour History, no. 15 (November 1968): 40-48.

38. R. M. Harney, "Organisational Conflicts in the Queensland Labour Movement, 1888-1893," Labour History, no. 4 (May 1963): 19-35; G. L. Buxton, “Incident at Barcaldine, 1891," Labour History, no. 7 (November 1964): 22; Eric Fry, “Queensland Parliamentary Papers, 1860-1900," Labour History, no. 8 (May 1965): 37-45.

39. Stoodley, "The Development of Gold-Mining Unionism"; June Stoodley, "Queensland Miners' Attitudes towards the Need for Safety Regulations," Labour History, no. 14 (May 1968): 23-33.

40. Denis Murphy, "The Establishment of State Enterprises in Queensland, 1915-18," Labour History, no. 14 (May 1968): 13-22.

41. John Merritt, "George Foster Pearce and the Perth Building Strike of 1897," Bulletin for the Study of Labour History, no. 3 (November 1962): 5-22. Another article was based on a UQ Honours degree in economics: S. K. Proctor, "History of the Brisbane Branch of the Plumbers and Gasfitters 
The transformation of the UQ Department from laggard to leader in labour history research can be dated to a series of fortuitous events initiated by Tom Burns, Labor's Queensland Secretary, in 1967. As Murphy later recorded, Burns approached "us at the Uni to write the full history of the ALP in Queensland," believing that such a history could "be completed in about three to four weeks." 42 Someone (almost certainly Murphy) came up with a solution to placate Burns, who was clearly looking for a material outcome from Labor's past generosity towards Departmental research students. Over a period of a few months in 1967-68 the manuscript for a book, which became Prelude to Power, was compiled by cannibalising many of the Department's labour history theses. Nine of the 19 chapters that appeared in the book were abbreviated Departmental theses. A tenth, by S. K. Proctor ("Brisbane Unionism and the Plumbers Union"), was based on a thesis completed in UQ's Economics Department. An eleventh chapter, on colonial printing unions, was obtained from Jim Hagan, who was visiting Brisbane as part of his PhD studies. To this collection, Murphy added four chapters: "The Changing Structure of the Party," "T. J. Ryan," "Two Administrators - Albert Hinchcliffe and Matt Reid," and "Four Parliamentary Leaders." Additional chapters came from University librarian, B. J. Guyatt ("The Labour Press, 1880-1915"), John Fowler ("The Queensland Economy, 1860-1915") and Colin Hughes, UQ's Professor of Political Science ("Labour in the Electorates").

While the manuscript for Prelude to Power was submitted in April 1968 it was more than two years before it was released by Brisbane's Jacaranda Press. Despite this delay, its publication proved a seminal moment in Queensland labour history. For the first time, as the editors (Murphy, Joyce and Hughes) noted, a cross-section of the labour history theses "written for the Queensland University's Department of History" was made "available to a wider public." 43 With a few exceptions, most notably the chapters by Stoodley and Crook, most authors shared the view enunciated by Dalton's opening piece: that Labor was moderate, not socialist, from the start and that it only succeeded when it eschewed radical causes. Methodologically, Murphy, having been granted access to Queensland Labor's Central Executive minutes in 1967, broke new ground with his chapter, "The Changing Structure of the Party," providing an "insider's view" of Labor's internal machinations. Conceptually, Murphy readily incorporated many of the themes articulated in Dalton's chapter. However, Murphy differed from the likes of Greenwood and Dalton by arguing that Labor was the only viable institution for achieving socially beneficial reforms. As Murphy indicated in Prelude to Power, Labor was unique in providing both the means for reform through "a strong union-based political party" and a "pragmatic" approach that emphasised "immediate improvement" over hazy "utopias." 44 This pragmatic emphasis accorded with Murphy's vision for the contemporary party, which he believed could only succeed by appealing to the growing professional middle class. As Murphy advised Bob Hawke, people "just don't vote for us in ... [newer] housing areas where the 23-45 year olds live." 45

Employees Union of Australia, 1904-1919," Labour History, no. 13 (November 1967): 26-32.

42. Murphy to Dickey, 25 March 1970.

43. D. J. Murphy, R. B. Joyce and Colin Hughes, "Introduction," in Murphy, Joyce and Hughes, Prelude to Power, 222;

44. D. J. Murphy, "Two Administrators," in Murphy, Joyce and Hughes, Prelude to Power, 222; D. J. Murphy, "The Changing Structure of the Party," in Murphy, Joyce and Hughes, Prelude to Power, 132.

45. Denis Murphy to Bob Hawke, 5 June 1974, Folder 3, Box 40, UQFL129. 


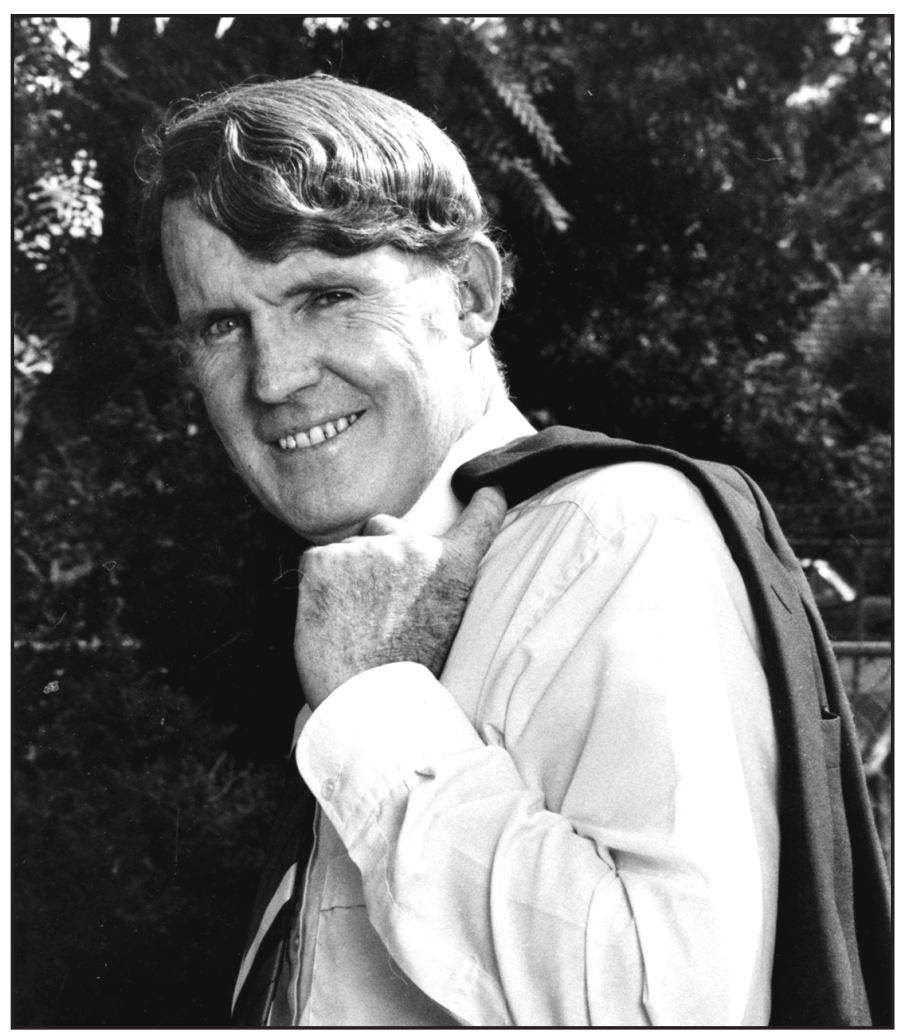

Denis Murphy, 1983

Courtesy: Dr Denis Murphy Collection, Fryer Library, University of Queensland

In terms of Murphy's career, the mere compilation of the Prelude to Power manuscript guaranteed future publications by bringing him to Thompson's attention. Impressed by the organisation of Prelude to Power, in 1968 Thompson advised Murphy to spread the ambit of his publications to Australia as a whole. From this proposal emerged Labor in Politics. Optimistically, Thompson informed Murphy that he believed the proposed book would "boost his sales and profits." ${ }^{46}$ In 1970, Thompson also asked Murphy to bring to print a book on "significant figures in Queensland politics," a suggestion that later manifested itself as Queensland Political Portraits. ${ }^{47}$

In contrast to Prelude to Power, the writing of Labor in Politics proved a nightmare. Murphy, a virtually unknown prior to the publication of Prelude to Power, had difficulty in attracting authors. Gollan, Geoffrey Serle and Ian Turner all turned down offers to contribute. Of those who agreed, Bede Nairn and Humphrey McQueen proved problematic. Nairn's New South Wales (NSW) chapter blew out to book length. McQueen, whose New Britannia was published in 1970, refused to do empirical research for his Victorian chapter. When Murphy chided him, McQueen declared that his "revolutionary approach" was based around theoretical synthesis (his chapter was retained). ${ }^{48}$ As the years ticked by those authors who had submitted

46. Denis Murphy to Brian Dickey, 17 September 1970, Folder 3, Box 40, UQFL129.

47. Denis Murphy to Contributors to Labor in Politics, 30 August 1970, Folder 10, Box 40, UQFL129.

48. Denis Murphy to Humphrey McQueen, 20 November 1969, Folder 3, Box 40, UQFL129; Humphrey 
became irate over Murphy's patience with the laggards, most notably Nairn. Murphy's failings on this front reflected the fact that Nairn was also flagged as an Examiner for his PhD. It was only when Nairn's favourable report was in hand in mid-1972 that Murphy culled him, approaching Peter Loveday to take over the NSW chapter. ${ }^{49}$ While Nairn was not too dismayed by this solution, his draft becoming the basis for Civilising Capitalism, the change further delayed publication. Not until 1975, eight years after commissioning, was UQP able to publish. ${ }^{50}$

Despite the tribulations associated with Labor in Politics, UQP were presumably buoyed by a review of the manuscript provided in 1973 by John Merritt. While unhappy with "McQueen's interpretation," Merritt nevertheless concluded that the book would make "an important contribution to the historiography of political Labor." ${ }^{11}$ Murphy's chapter provided what was to be the most detailed study of his career on Queensland Labor. He also used the book's introduction to enunciate the principles upon which labourism was based, foreshadowing Hagan's later, better known definition. The unions, he observed, were Labor's "sheet anchor," providing "finance and organisers." In return, Labor governments helped "unions to expand their industrial strength." ${ }^{2}$

Murphy's cautious dealings with Nairn during the compilation of Labor in Politics highlighted his precarious career placement in the early 1970s. As noted in the introduction, this was demonstrated when Greenwood intervened in Murphy's PhD examination process after Crisp advised, in April 1972, that he was "unable to recommend acceptance." 53 Fortunately for Murphy this situation was soon remedied, Crisp informing the University the following month that: "I accept Professor Greenwood's assurance ... that the deposit copy is being overhauled." ${ }^{54} \mathrm{As}$ is the case with most academic careers, obtainment of a PhD transformed Murphy's situation. Promoted to Senior Lecturer in 1975, Murphy became a Reader (Associate Professor) in 1979. With Murphy's thesis approved, Thompson promptly offered to publish it through UQP. As a result, Murphy benefited from two book launches in 1975, T. J. Ryan: A Political Biography joining the much delayed Labor in Politics: the State Labor Parties in Australia 1880-1920. Thompson spared no expense in launching the latter, flying Bob Hawke up from Melbourne (all expenses paid) to preside over the occasion. Gough Whitlam carried out similar duties for T. J. Ryan. ${ }^{55}$

In 1975, publication of Queensland Political Portraits also appeared near. Murphy advised contributors that the manuscript was complete "except for one chapter." Two years later, agreement was formalised for yet another UQP book, Labor in Power. ${ }^{56}$ Beneath the surface, however, problems were emerging. In terms of Murphy's own research, warning signs were flagged in Crisp's Examiner's Report. Crisp's concerns were not with the thesis's substance but rather with its compilation, noting that it was

McQueen to Denis Murphy, c. April 1970, Folder 3, Box 40, UQFL129.

49. Denis Murphy to Peter Loveday, 6 July 1972, Folder 3, Box 40, UQFL129.

50. A fuller account of the writing of Labor in Politics is in Bongiorno, "The Importance of Being Practical," 31-53.

51. John Merritt to Frank Thompson, 18 June 1973, Denis Murphy Folder, Box 346, UQFL198.

52. D. J. Murphy, "Introduction," in Murphy, Labor in Politics, 9; Jim Hagan, The History of the ACTU (Melbourne: Longman Cheshire, 1981), 14.

53. Crisp, Examiner's Report on PhD Thesis of D. J. Murphy.

54. Crisp to Munro.

55. Frank Thompson to Bob Hawke, 6 March 1975, Box 346, UQFL198.

56. University of Queensland Press, Memorandum of Agreement with Denis Murphy and Roger Joyce, 31 March 1977, Box 345, UQFL198. 
full of grammatical errors and, at 190,000 words, "double the normal length." ${ }^{57}$ The thesis's unpolished finish undoubtedly reflected the fact that Murphy was taking on much work on many fronts. Within the History Department he drove an expansion of Australian history offerings that lifted enrolments in this field from 96 in 1971 to 870 in 1974. ${ }^{58}$ Staff numbers in the field, however, failed to rise in line with enrolments. Although Evans was recruited as a Lecturer in 1975, with Saunders serving as a Tutor, such gains were offset by the departure of Joyce - who had long taught in the field - for La Trobe University in late 1974. From 1970, Murphy also served as Chair of the Departmental Assembly. Established to restrain Greenwood's power, this job involved endless rounds of vociferous meetings. Within the Labor Party, Murphy was not only a Queensland Central Executive member but also Labor's candidate for Petrie in the 1972 federal election, a seat which he lost by a mere 30 votes.

Inevitably, there had to be a cost from the workload Murphy assumed. Typically, Murphy's work has been criticised for an absence of theory, Bongiorno accurately observing that he remained rooted to "older [empirical] traditions of political and industrial history. ${ }^{\prime \prime 9}$ In all probability, a more leisured life would not have addressed such problems. Murphy was, by all accounts, practical by temperament. Instead, the cost of his workload was found in the curtailment of his greatest strength: original empirical research. Increasingly, Murphy was guilty of the sin that he once accused McQueen of committing: providing syntheses of the work of others without checking its veracity. This becomes apparent in Queensland Political Portraits, where Murphy wrote chapters on William Kidston, T. J. Ryan and Ted Theodore. Significantly, a draft manuscript for this book had been circulating for decades. In 1955, Greenwood offered Angus \& Robertson $£ 400$ if they published "Political Portraits," a work which he indicated he had compiled with "Dr [Colin] Roderick and Mr [Colin] Hughes." ${ }^{\prime 60}$ By 1970, Murphy had taken control of this project following Thompson's promise to publish, demanding revisions to earlier work and commissioning new chapters. To complete his own chapters, Murphy drew on his PhD for the Ryan chapter and on Departmental theses for the other two. As Murphy advised Joyce, "Much to my private typist's amazement I have raided the thesis library to begin the Theodore chapter." ${ }^{16}$ This reliance on earlier work, much of which was now published, meant that Murphy's chapters broke little new ground. His chapter on Kidston differed little from the one that had appeared under Wanka's name in Prelude to Power.

Shifting fortunes are also evident when we consider publications within Labour History. Between 1971 and 1974 all four of the Queensland-themed articles published came from authors associated with the UQ History Department. One was from Murphy on the Dawson Government of 1899. Two came from Margaret Cribb, who

57. Crisp, Examiner's Report on PhD Thesis of D. J. Murphy.

58. Australian and American Studies Section, UQ History Department, Minutes, 7 August 1977, Box 33, UQFL129.

59. Bongiorno, "The Importance of Being Practical," 45. Similarly, Evans ("Reconsidering Murphy and Ryan," 59) observes that Murphy "had little time for Marxist - or ... any other - theory."

60. Gordon Greenwood to A. A. Ritchie (Angus \& Robertson), 5 July 1955, Folder 8, Box 5, UQFL516. Note: Colin Roderick was a noted literary critic and historian who worked as an Editor for Angus \& Robertson during the 1950s and early 1960s. In 1965 he was appointed Professor of English at what subsequently became James Cook University. Queensland's most prestigious literary award, the Colin Roderick Award, is named in his honour.

61. Denis Murphy to Roger Joyce, 11 March 1975, Folder 10, Box 40, UQFL129. 
wrote about the Queensland Railways Union. Costar, who was completing his $\mathrm{PhD}$ in the Government Department but teaching in history, wrote the fourth. ${ }^{62}$ By contrast, the only Queensland-themed articles from the Department between 1975 and 1978 were Saunders' study of race in the sugar industry and Joy Guyatt's paper on the Shearers' Strike of $1956 .{ }^{63}$ A greater number of Queensland-themed articles came from James Cook University - an institution that rapidly emerged as an alternative centre for Queensland labour and social history - where Doug Hunt published one paper to Kett Kennedy's two. Another article, "The 1919 Meat Strike in Townsville," was from Wollongong-based Terence Cutler. ${ }^{64}$

The period around 1974 also saw a marked change in the theses completed within the UQ Department. As Table 1 indicates, between 1970 and 1976 the Department witnessed the submission of 18 labour history themed theses, five of which were PhDs. After 1974, however, there was a marked shift towards New Left topics. Whereas only three theses completed prior to 1975 were on New Left themes Kathryn Cronin's PhD (Chinese in Queensland), Jim Prentice's Master's Qualifying (the New Left) and Carmel Shute's Honours thesis (Women and the Great War) - all but one of those completed after this date (Rosemary Gill's thesis on T. J. Byrne being the exception) eschewed "traditional" topics. The vigour of New Left social history was emphasised in 1975 when Evans, Saunders and Cronin published Exclusion, Exploitation and Extermination: Race Relations in Colonial Queensland. ${ }^{65}$ However, even New Left topics suffered after 1976. There is no evidence of labour history Honours or Master's theses being submitted between 1977 and 1980. New Left research also failed to enjoy the favour of "traditional" topics in UQP's print-room, Exclusion, Exploitation and Extermination being published by a small Sydney publisher. The difficulties the latter work had in achieving publication also reflected a growing animus against New Left research from those in the UQ Department who favoured more traditional topics. Gordon Greenwood denied the manuscript the normal Departmental subsidy. ${ }^{66}$

\section{Shifting Sands, 1978-83}

A central element in Murphy's publication success was his partnership with Roger Joyce and Colin Hughes. In 1977, this triumvirate appeared almost an institution

62. D. J. Murphy, "The Dawson Government in Queensland," Labour History, no. 20 (November 1970): 1-8; Margaret Cribb, "The ARU in Queensland," Labour History, no. 22, (May 1972): 13-22; Margaret Cribb, "State in Emergency," Labour History, no. 24 (May 1973): 225-48; B. J. Costar, "The Great Depression: Was Queensland Different?," Labour History, no. 26 (May 1974): 32-48.

63. Kay Saunders, "Masters and Servants," Labour History, no. 35 (November 1978): 96-111; Joy Guyatt, "The Labor Government and the Queensland Shearers' Strike of 1956," Labour History, no, 33 (November 1977): 53-64. In addition, there were two articles on the German labour movement: John Moses, "Bureaucrats and Patriots: The German Socialist Trade Union Leadership from Sarajevo to Versailles," Labour History, no. 30 (May 1976): 1-21; John Moses, "The Concept of Economic Democracy within the German Socialist Trade Unions during the Weimar Republic," Labour History, no. 34 (November 1978): 45-57.

64. K. H. Kennedy, "The South Johnstone Strike and Railway Lockout, 1927," Labour History, no. 31, (November 1976): 1-13; K. H. Kennedy, "Theodore, McCormack and the Amalgamated Workers' Association," Labour History, no. 33 (November 1977): 14-28; Doug Hunt, "Exclusivism and Unionism," Labour History, no. 35 (November 1978): 80-95; Terrance Cutler, "Bloody Sunday," Labour History, no. 24 (May 1973): 81-102.

65. Raymond Evans, Kay Saunders and Kathryn Cronin, Exclusion, Exploitation and Extermination: Race Relations in Colonial Queensland (Sydney: Australian and New Zealand Book Co., 1975).

66. This information was provided by one of the two reviewers of this article. 
as UQP agreed to yet another book proposal, which appeared three years later as Labor in Power. Behind the scenes, however, tensions were emerging. This became evident in the finalisation of Queensland Political Portraits. To the dismay of Joyce and Hughes, Murphy wished to extend discussion so as to encompass contemporary Queensland politics, writing, "The Picture Changes: Queensland Politics 1952-74." Much of this involved an attack on Queensland's then Premier, Joh Bjelke-Petersen. So as to torpedo this addition, Joyce and Hughes came up with an all-too clever plan. They had UQP request an "independent" review, which Hughes, who was by now Professor of Politics at the ANU, then wrote in condemnation. This was then forwarded to Murphy with Hughes' name removed ${ }^{67}$ It is hard to believe that Murphy, an acutely political animal, failed to see through this ploy. With evident displeasure, he advised UQP to "delete it [the chapter] entirely." 68

Differences between Murphy and his two co-editors are also evident in Labor in Power. In 1978 a nearly complete manuscript was savaged in a (genuinely) independent review provided by Bede Nairn. While sharing Murphy's "labourist" views, Nairn nevertheless attacked the book's uncritical discussions of Labor and its affiliated unions. If the editors were worried that a critical analysis would alienate "ALP bosses and the trade union heavies," Nairn advised, than they should not worry, as this constituency "would be breaking the habits of a lifetime if they showed any real interest in this book." ${ }^{69}$ The effects of Nairn's admonishment can be seen in Labor in Power's published introduction. Appearing with only Joyce's name appended, and drawing on Michel's dictums about political "oligarchies," it observed that an Australian Workers Union dominated elite increasingly controlled Queensland Labor, demanding "conformism" from members. ${ }^{70}$ This assessment differed markedly from Murphy's chapters, where it was argued that if an "oligarchy ruled the Labor party," it "was an oligarchy that was able to tap rank and file and union views." ${ }^{\prime 1}$ Labor in Power proved to be the last book which the triumvirate were to publish together.

If the writing of Queensland Political Portraits and Labor in Power exposed growing differences between Murphy and his co-editors, its publication also proved disastrous for Thompson at UQP. By 1976, two years before the launch of Queensland Political Portraits, UQP's fiction editor, Craig Munro, was sounding the alarm. This "will be a very expensive book," Munro warned his fellow manager, that "will lose financially." 72 Such counsels cast a pall over the other books that Thompson and Murphy anticipated would be published through UQP, these being Labor in Power, "Strikes in Queensland" (subsequently The Big Strikes) and a sequel to Labor in Politics covering the years between 1916 and 1957 (this never eventuated). ${ }^{73}$ When in late 1978

67. Roger Joyce to Merril Yule and Frank Thompson, 7 April 1976, Box 345, UQFL198; Craig Munro to Colin Hughes, 29 April 1976, Box 345, UQFL; Colin Hughes to Craig Munro, 7 May 1976, Box 345, UQFL198.

68. Denis Murphy to Craig Munro, Box 345, UQFL198.

69. Bede Nairn, Reader's Report on Labor in Power, 29 November 1977, 4-5, Box 345, UQFL198.

70. R. B. Joyce, "Introduction," in Murphy, Joyce and Hughes, Labor in Power, xxi.

71. Denis Murphy, "Organisation, Structure and Finance," in Murphy, Joyce and Hughes, Labor in Power, 36.

72. Craig Munro to Frank Thompson, 18 August 1976, Box 345, UQFL198. Munro was appointed UQP's inaugural fiction editor in 1971, subsequently replacing Thompson as publishing manager. Munro's long UQP career is recorded in, Craig Munro, Under Cover: Adventures in the Art of Editing (Melbourne: Scribe, 2015).

73. Denis Murphy to Duke University, 7 April 1975, Box 33, UQFL129. 
UQP's Publication Committee (which still included Greenwood) recommended that the 480-paged Labor in Power be included among the Press's forthcoming imprints the University's Deputy Vice-Chancellor rejected the recommendation. The University also began an "investigation" into Thompson's management. ${ }^{74}$

To rescue matters Thompson had, even before the rejection of the Committee's recommendation, approached Greenwood for a $\$ 1,000$ subsidy for Labor in Power. This begs the question of why Thompson failed to gain Greenwood's assistance, at a time when he was subsidising books by other Departmental members, to help him out with Queensland Political Portraits. The most obvious explanation is that Greenwood was more enthusiastic about assisting factional friends write diplomatic history than he was about helping foes write labour and political histories. As it transpired, Greenwood appears to have approved the subsidy, but not actioned it, prior to his removal as Head. ${ }^{75}$ This forced Murphy to follow up the matter with Malcolm Thomis, the new Head, in November 1978. After initially indicating approval, however, Thomis reneged, blaming Departmental opposition. ${ }^{76}$ Ultimately, Labor in Power was published by UQP, the University forced to honour the commitments made in its name. Although it appears a close run thing, in 1982 Murphy also secured a contract for The Big Strikes, which was published the following year. ${ }^{77}$ Murphy was, however, forced to find another publisher (Angus \& Robertson) for his biography of the then federal Opposition leader, Bill Hayden. Even if UQP was financially better placed it was unlikely that the Hayden manuscript would have passed muster with the independent reviewer that UQP now demanded. Even Murphy's close Labor ally, Peter Beattie, found the work to be a hagiography, advising him that "you are too pro-Hayden ... You say very few critical things." ${ }^{\prime 7}$

By 1983, even as Murphy celebrated the launch of The Big Strikes, the factors that had underpinned labour history publications from within the UQ History Department were disappearing. The store of research in the Department's theses shelves was largely exhausted. UQP's once strong publication support was evaporating. Even Murphy's once close relations with New Left staff members, most particularly Evans, deteriorated. By the time Murphy was elected to Parliament the two were, as Evans notes, barely speaking. ${ }^{79}$ So unhappy was Murphy with the research of his former protégé that he opposed Evans' promotion in $1981 .{ }^{80}$ Difficult times were also evident in teaching, where enrolments in Australian history courses plummeted after 1976. As student numbers fell so too did staff employment. Taking a more prosaic attitude to University cost-reductions than Greenwood, Thomis bluntly advised staff in 1982 that they had to face the "elimination of our tutorial staff." 81

Murphy's departure for Parliament, and his subsequent death, heralded the end of a seminal period for Queensland labour history. But the discipline continued

74. Page to Frank Thompson; Merril Yule to Denis Murphy, 10 November 1981, Box 346, UQFL198.

75. Merril Yule to Malcolm Thomis, 5 April 1979, Box 345, UQFL198.

76. Malcolm Thomis to Merril Yule, 10 April 1979, Box 345, UQFL198.

77. University of Queensland Press, Contract: "Big Strikes," 26 October 1981, Denis Murphy Folder, Box 346, UQFL198.

78. Peter Beattie, Comments on Bill Hayden MSS, c. 1977, Box 9, UQFL129.

79. Evans, "Reconsidering Murphy and Ryan," 55-56.

80. Denis Murphy to Dr S. A. Raynar re R. L. Evans Application for Promotion, 16 June 1981, Box 2, UQFL 129.

81. Malcolm Thomis, Communications that Seem to be Important, 1 June 1982, unpublished note to UQ History Department staff, Box 32, UQFL129. 
to thrive, carried forward in less propitious circumstances. Initially, much of this research focused on race relations. UQ-trained historians remained prominent in such endeavours, most particularly Saunders, Evans, Scott and Joanne Watson, all of whom published articles on race in Labour History. ${ }^{82}$ Increasingly, however, JCU became the leading Queensland centre in this field with notable contributions from Henry Reynolds and Dawn May. ${ }^{83}$ It would be wrong, however, to believe that Queensland labour historians lost interest in "traditional" themes (unions, strikes and politics), these themes being covered in depth in Work \& Strife in Paradise: The History of Labour Relations in Queensland 1859-2009, a collection of studies prepared for Queensland's sesquicentenary. ${ }^{84}$ Of this journal's current Editorial Board members, three (Glenda Strachan, Bradley Bowden and Beris Penrose) are graduates of the UQ History Department, ${ }^{85}$ an institution where the legacy of its "golden age" of labour history research long lingered. For all of those who have ventured into Queensland labour history, moreover, an awareness of UQ's earlier body of research - not only Murphy's publications but also the Department's thesis collection - has been an imperative. This is not to say that there were no weaknesses in the UQ History Department. As previously noted, its strength was empirical research rather than grand theory. Little of the UQ work, and none of Murphy's, covered the period prior to 1880. There was, and still is, a comparative dearth of research into nonmetropolitan labour history (Barbara Webster's more recent work on Rockhampton aside). There are still relatively few histories of Queensland unions. Nevertheless, those of us who have conducted Queensland labour history research since 1983 have continually stood on the shoulders of those who previously laboured in the UQ History Department.

\section{Conclusion}

It is tempting to see the advances that characterised Australian labour history during the 1960s and 1970s as stemming from common sources: the intellectual legacy of the "Old Left," the central role of organised labour in national life and the employment opportunities offered by expansion of the higher education sector. However, in Queensland, this study has argued, the academic discipline had its own pioneers, most of whom were found within the UQ History Department. While this Queensland source can be traced back to 1947 and Rayner's Master's thesis, "The Evolution of the Queensland Labour Party to 1907," until 1970 the growing store of labour history research was hidden in Departmental theses cabinets. That this body

82. Kay Saunders, “Inequalities of Sacrifice: Aborigines and Torres Strait Islander Labour in Northern Australia during the Second World War," Labour History, no. 69 (November 1995): 131-48;

Raymond Evans and Joanne Scott, "'Fallen among Thieves': Aboriginal Labour and State Control in Inter-War Queensland," Labour History, 69 (November 1995): 115-30; Joanne Watson, “'Couldn't Tolerate any More': The Palm Island Strike of 1957," Labour History, no. 69 (November 1995): 149-70.

83. In particular: Henry Reynolds, The Other Side of the Frontier: Aboriginal Resistance to the European Invasion of Australia (Ringwood: Penguin, 1982); Henry Reynolds, With the White People (Ringwood: Penguin, 1990); Dawn May, From Bush to Station: Aboriginal Labour in the North Queensland Pastoral Industry, 1861-1892 (Townsville: James Cook University, 1983).

84. Bradley Bowden, Simon Blackwood, Cath Rafferty and Cameron Allan, eds, Work \& Strife in Paradise: The History of Labour Relations in Queensland 1859-2009 (Sydney: Federation Press, 2009).

85. Strachan did her Honours degree under Murphy in 1972. Bowden completed an Honours degree in the Department between 1973 and 1977, although his thesis was on anti-colonial revolutions. Penrose completed a PhD thesis on the Communist Party of Australia in the Department in 1993. 
of research was brought to public view and expanded upon between 1966 and 1983 owed much to not only the personal efforts of Denis Murphy but to a coincidence of factors. The Queensland Labor Party under the Secretaryship of Tom Burns favoured researchers, providing the impetus for Prelude to Power, a work which incorporated a cross-section of Departmental theses. Within the University, Murphy found senior mentors - most notably Joyce and Hughes - who helped foster publication, co-editing Prelude to Power, Labor in Power and Queensland Political Portraits. UQP's long-term manager, Frank Thompson, also played a key role, publishing all but two of Murphy's books (Prelude to Power and Bill Hayden). In his own work, Murphy built on the earlier Departmental traditions of labour history. Like most of his UQ compatriots, Murphy held that the Labor Party was subject to a constant internal war between radicals and moderates and that electoral success only came when the latter were in the ascendancy. Murphy, however, differed in believing that only a union-based party had the deep social foundations necessary for enduring representation and reform.

If the conjuncture of forces that characterised the UQ History Department in the late 1960s and early 1970s favoured labour history publications, they were nevertheless inherently transient. Queensland Labor showed little further interest in labour history after Prelude to Power. Murphy's early mentors, Joyce and Hughes, increasingly disagreed with his "labourist" interpretations. At UQP, Thompson's position became precarious as the labour history publications he favoured incurred mounting losses. As the 1970s progressed the "traditional" labour history which the department long fostered (electoral politics, unionism and political biographies) also found itself out of tune with the times. Fewer people studied labour history. Those that did tended to be more interested in New Left topics: race, gender and the effects of war. Despite such trends, however, the changed circumstances that characterised the UQ History Department in the late 1970s represented not an end but new beginnings. For all those interested in Queensland labour history, moreover, the publications from this "golden era" still provide empirical and intellectual bedrocks.

Bradley Bowden is Professor of Employment Relations at Griffith University and Chair Elect of the Management History Division of the Academy of Management. He is Editor-inChief of the Journal of Management History and a long-term contributor to Labour History, this article being his twelfth.

$<$ b.bowden@griffith.edu.au> 